\title{
Prevalence of parasitic infection in captive non human primates of Assam State Zoo, I ndia
}

\author{
Bichitra Gopal Nath ${ }^{1}$, Saidul Islam², Apurba Chakraborty ${ }^{3}$ \\ 1. ICAR-RC for NEH Region, Sikkim Centre, Tadong-737102, Sikkim, India \\ 2. Department of Parasitology, College of Veterinary Science, Assam Agricultural University, Khanapara- \\ 781022, Assam, India 3. Director of Research (Veterinary), College of Veterinary Science, Assam \\ Agricultural University, Khanapara-781022, Assam, India \\ Corresponding author: Bichitra Gopal Nath, email:drbichitra.nath@gmail.com \\ Received: 14-03-2012, Accepted: 25-04-2012, Published Online: 30-07-2012 \\ doi: $10.5455 /$ vetworld.2012.614-616
}

\begin{abstract}
Aim: The study was conducted to know the parasitic infestation in captive non human primates of Assam State Zoo.

Materials and Methods: A total of twenty two faecal samples from non human primates of different species viz. Slow loris (Nycticebus coucang) (3), Pig tailed macaque (Macaca nemestrina) (3), Stump-tailed macaque (Macaca arctoides) (5), Assamese macaque (Macaca assamensis) (1), Bonnet macaque (Macaca radiata) (1), Golden langur (Trachypithecus geei) (6) and Hoolock gibbon (Hylobates hoolock) (3) were analysed from August, 2009 to December, 2009 by using routine sedimentation and floatation techniques as described by Georgi (1985). Identification of parasitic ova was carried out as described by Soulsby (1982) and Wallach and Boever (1983).

Results: Out of 22 faecal samples examined, $1(20 \%)$ in stump-tailed macaque was found positive for Oesophagostomum spp. and 1(16.67\%) in golden langur and $1(33.33 \%)$ in hoolock gibbon, were found positive for the presence of Trichuris spp. Conclusion: Incidence of parasitic infection was $13.63 \%$ in captive non human primates of Assam State Zoo.

Key words: Assam State Zoo, non human primates, parasites

\section{To cite this article:}

Nath BG, Islam S, Chakraborty A (2012) Prevalence of parasitic infection in captive non human primates of Assam State Zoo, India, Vet World, 5(10): 614-616, doi: 10.5455/vetworld.2012.614-616
\end{abstract}

\section{I ntroduction}

Whether living in the wild or in captivity, nonhuman primates are beset with a variety of diseases including an extensive list of parasite infections [1]. Parasitic diseases of wildlife are still in infancy in India and data are still on the base line [2]. These diseases constitute one of the major problems in management causing mortality and morbidity in wild animals in captivity [3]. Parasites of captive nonhuman primates generally are more limited than those reported for field studies and in wild-caught primates [4]. High levels of parasitism in captive animals can be attributed to abnormally high densities, cross-species transmission, and stress due to cold, fighting, caging, and confinement which exacerbate parasitic infections to the point of even causing death. The capture and quarantine of animals upon onset of captivity may result in high stress levels [5], and infection can be exacerbated by the confinement and stress primates experience in these captive environ-ments [6]. Study of parasitic infection in captive non human primates is important to know the infection rate to prevent from morbidity and mortality of animals in the zoo.
The present study was conducted to provide the baseline data of fecal parasites in captive non human primates of Assam State Zoo.

\section{Materials and Methods}

Fresh stool sample (10-15 gram) was collected from non human primates of different species viz. Slow loris (Nycticebus coucang) (3), Pig tailed macaque (Macaca nemestrina) (3), Stump-tailed macaque (Macaca arctoides) (5), Assamese macaque (Macaca assamensis) (1), Bonnet macaque (Macaca radiata) (1), Golden langur (Trachypithecus geei) (6) and Hoolock gibbon (Hylobates hoolock) (3) during the period from August, 2009 to December, 2009. The samples were properly labeled indicating name, age, sex, species and date of collection and were examined at Department of Parasitology, College of Veterinary Science, Assam Agricultural University, Khanapara, Guwahati. Fecal samples were examined using concentration via sodium chloride floatation (for separating helminth eggs and protozoan cysts) and fecal sedimentation (for identification of trematodes) as described by Georgi [7]. Identification of parasitic 
Table-1. Showing the prevalence of parasitic infection in captive non human primates at the Assam State Zoo

\begin{tabular}{lcclc}
\hline Non human primate species & $\begin{array}{c}\text { No. of animal } \\
\text { examined }\end{array}$ & $\begin{array}{c}\text { No. of infected } \\
\text { (\%) }\end{array}$ & Ova of helminth & $\begin{array}{c}\text { Intensity of } \\
\text { infection* }\end{array}$ \\
\hline Slow loris (Nycticebus coucang) & 3 & 0 & $-v e$ & - \\
Pig tailed macaque (Macaca nemestrina) & 3 & 0 & $-v e$ & - \\
Stump-tailed macaque (Macaca arctoides) & 5 & $1(20.00)$ & Oesophagostomum sps. ++ \\
Assamese macaque (Macaca assamensis) & 1 & 0 & $-v e$ & - \\
Bonnet macaque (Macaca radiata) & 1 & 0 & $-v e$ & - \\
Golden langur (Trachypithecus geei) & 6 & $1(16.67)$ & Trichuris sps. & ++ \\
Hoolock gibbon (Hylobates hoolock) & 3 & $1(33.33)$ & Trichuris sps. & + \\
Total & $\mathbf{2 2}$ & $\mathbf{3 ( 1 3 . 6 3 )}$ & & + \\
\hline
\end{tabular}

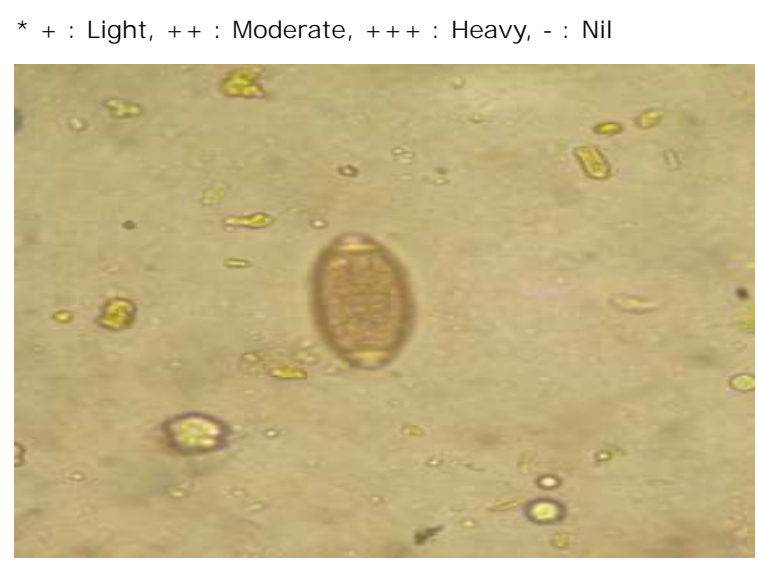

Fig 1. Photograph showing ova of Trichuris spp. $X 400$

ova was carried out as described by Soulsby [8] and Wallach and Boever [9].

\section{Result}

Out of 22 , only 3 animals were found to be positive for parasitic infestation. The study recorded ova of Trichuris spp. (Fig.1) in golden langur (1) and hoolock gibbon (1) and Oesophagostomum spp. (Fig. 2) in stump-tailed macaque (1). The result of the investigation on the basis of faecal examination is presented in Table 1.

\section{Discussion}

The parasitic infection in non human primates were also recorded earlier by Lisa et al [10], KalemaZikusok et al. [11], Sanchez et al. [12], Ascaratte et al. [13]. Munene et al. [14] recorded Strongyloids, Schistosoma mansoni, Streptopharagus spp., Entamoeba coli, Balantidium coli and Entamoeba histolytica in non human primates whereas Parmar [15] recorded Strongyloides spp., Trichuris spp., Entaemoeba histolytica spp., Ascaris spp. Entamoeba coli, Spirometra spp. in hanuman langur and rhesus macaques of Gujrat state. In addition to the parasites recorded in the present

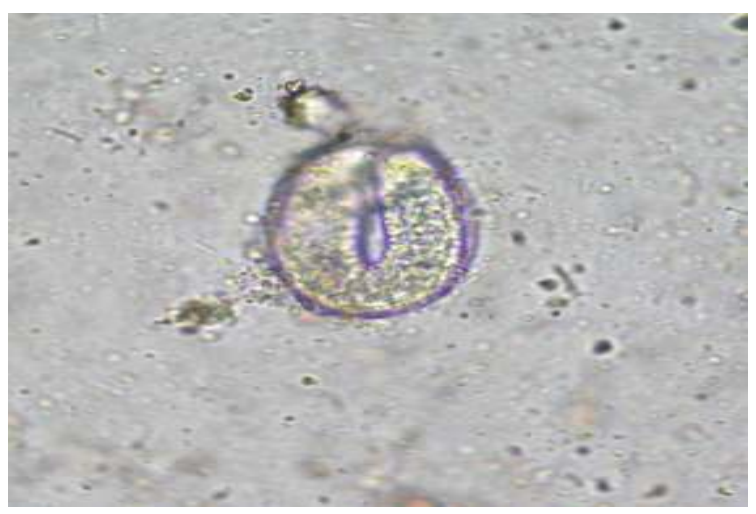

Fig 2. Photograph showing ova of Oesophagostomum spp. $\times 400$

study, Goswami [16] documented Ascaris, Enterobius, Anchylostoma, Strongyloids, Entamoeba, Giardia and Balantidium spp. in non human primates of Assam State Zoo.

The rate of infection seen in this study was lower than the rate of incidence recorded by the earlier workers. As the faecal samples examined were from the caged non human primates of the Assam State Zoo and due to periodical use of anthelmintics might be the reason of low incidence found in the study. The lower prevalence of parasitic infection in captive non human primates was similar with the findings of Legesse and Arko [17] and Lilly et al. [18]. As some parasites have indirect life cycle, the intermediate host have little chance to come in contact with captive animals and as such the incidence of cestode and trematode were found to be low [19].

\section{Conclusion}

Incidence of parasitic infection was $13.63 \%$ in captive non human primates of Assam State Zoo. The present study viewed that it is necessary to screening captive Non Human Primates of zoo for parasitic infection in a regular interval of time to control 
morbidity and mortality of animals.

\section{Author's contribution}

Bichitra Gopal Nath and Apurba Chakraborty designed the study as this was a part of Bichitra Gopal Nath's MVSc thesis and Apurba Chakraborty was his major advisor. Bichitra Gopal Nath collected faecal samples. Bichitra Gopal Nath and Saidul Islam examined the faecal samples. All authors read and approve the final manuscript.

\section{Acknowledgements}

The authors are grateful to the authority of Assam State Zoo for the materials and to the Head, Department of Pathology, College of Veterinary Science, Assam Agricultural University, Khanapara, Guwahati for providing the facilities to carry out the study.

\section{Competing interests}

Authors declares that they have no competing interests.

\section{nReferences}

1. Kuntz, R.E. (1982). Significant Infections in primate parasitology. Journal of Human Evolution. 11:185-194.

2. Islam, S (2006). Parasites and parasitic diseases of wildlife. Proceedings of XVII National Congress of Veterinary Parasitology and National symposium on "Strengths, challenges and opportunities in Veterinary Parasitology (Nov. 15-17, 2006), 43-52pp.

3. Rao, A.T. and L.N. Acharjyo (1984). Diagnosis and classification of common diseases of captive animals at Nandankanan zoo in Orissa (India). Indian Journal of Animal Health 23(2): 148-152.

4. Cathy A Johnson-Delaney (2009). Parasites of captive nonhuman primates. The veterinary clinics of North America Exotic animal practice. 12(3): 563-581 PubMed: 19732709 www.ncbi.nlm.nih.gov.

5. Woodford, M.H. and Rossiter, P. (1994). Disease risks associated with wildlife translocation projects. In: Olney, P. J. S., Mace, G. M. and Feistner, A. T. C. (eds.) Creative Conservation. London: Chapman and Hall.

6. Toft, J.D.I. (1986). The pathoparasitology of nonhuman primates: A review. In: Benirschke, K. (ed.) Primates: The Road to Self Sustaining Populations. NewYork: Springer-Verlag.
7. Georgi, J.R. (1985). Parasitology for Veterinarians. 4th ed. W.B. Saunders, London, 344.

8. Soulsby, E.J.L. (1982). Helminthes, Arthropodes and Protozoa of Domesticated animals. 7th ed. ELBS, Bailliere Tindall.

9. Wallach, J.D. and Boever, W.J. (1983). Diseases of Exotic Animals, Medical and Surgical Management. 1sted. W.B. Saunders Co. Philadelphia.

10. Lisa, J.E., Gregory, A.E., Michael, A.S., Jeffery, F., Umar, P. and Randall C.K. (2004). Prevalence of enteric parasites in pet macaques in Sulawesi, Indonesia. Am. J. Prim., 62(2):71-82.

11. Kalema-Zikusoka, G., Rothman, J.M. and Fox, M.T. (2005). Intestinal parasites and bacteria of mountain gorillas (Gorilla beringei beringei) in Bwindi Impenetrable National Park, Uganda. Primates. 46(1): 59-63.

12. Sanchez, V.V.V., Patino, A.S., Segundo, V.J.P., Sandoval, J.A.C., Esquivel, C.V.C and Sanchez, T.A.C. (2009). Prevalence of Gastrointestinal Parasites among Captive Primates in Panama, J.Anim. Vet. Adv. 8(12):2644-2649.

13. Ascaratte, J.C., Hervier, B., Carrillo, S.V., Sarabia, D.O., Luna, D.O. and Vea, J.J. (2010). Parasitic infections of three Mexican howler monkey groups (Alouatta palliata mexicana) living in forest fragments in Mexico. Prim., 51:231-239.

14. Munene, E., Otsyul, M., Mbaabu, D.A.N., Mutahi, W.T., Muriuki, S.M.K. and Muchemi, G.M. (1998). Helminth and protozoan gastrointestinal tract parasites in captive and wild-trapped African non human primates. Vet. Parasitol. 78(3): 195-201.

15. Parmar, S.M., Jani, R.G. and Mathakiya, R.A. (2012). Study of parasitic infections in non-human primates of Gujarat state, India. Vet. World, 5(6): 362-364.

16. Goswami, P.K. (1994). Studies on prevalence of pathological conditions of captive non human primate. M.V.Sc. thesis. Assam Agricultural University.

17. Legesse, M. and Erko, B. (2004). Zoonotic intestinal parasites in Papio anubis (baboon) and Cercopithecus aethiops (vervet) from four localities in Ethiopia. Acta Trop., 90:(3) 231-236.

18. Lilly, A.A., Mehlman, P.T. and Doran, D. (2002). Intestinal parasites in gorillas, chimpanzees and humans at Mondika Research Site, Dzanga-Ndoki National Park, Central African Republic. Ind. J. Prim. 23(3):555-557.

19. Chakraborty, A. (1991). Incidence and etiopathology on the mortality of captive wild herbivores in Assam. $\mathrm{Ph}$.D. thesis, Assam Agricultural University. 